\title{
A sensitive spectrophotometric method for the determination of sulfonamides in pharmaceutical preparations
}

\author{
PADMARAJAIAH NAGARAJA ${ }^{1 *}$ \\ SHAILENDRA D. NAIK ${ }^{2}$ \\ ASHWINEE KUMAR SHRESTHA ${ }^{1}$ \\ ANANTHARAMAN SHIVAKUMAR ${ }^{1}$ \\ 1 Department of Studies in Chemistry \\ University of Mysore, Manasagangothri \\ Mysore-570006, India \\ 2 Charak Pharma Pvt. Ltd., Silvassa \\ U. T. of Dadra Nagar Haveli \\ Silvassa-396230, India
}

\begin{abstract}
A new, simple and sensitive spectrophotometric method for the determination of some sulfonamide drugs has been developed. The method is based on the diazotization of sulfacetamide, sulfadiazine, sulfaguanidine, sulfamerazine, sulfamethazine, sulfamethoxazole, and their coupling with 8-hydroxyquinoline in alkaline media to yield red coloured products with absorption maxima at $500 \mathrm{~nm}$. Beer's law is obeyed from $0.1-7.0 \mu \mathrm{g} \mathrm{mL}^{-1}$. The limits of quantification and limits of detection were $0.11-0.18$ and $0.03-0.05$ $\mu \mathrm{g} \mathrm{mL}^{-1}$, respectively. Intraday precision (RSD $0.1-0.5 \%$ ) and accuracy (recovery 97.3-100.8\%) of the developed method were evaluated. No interference was observed from common adjuvants. The method has been successfully applied to the assay of sulpha drug in pharmaceutical formulations.
\end{abstract}

Keywords: sulfonamide drugs, diazotization, 8-hydroxyquinoline, spectrophotometry, pharmaceutical formulation

Sulfonamides, important analogues of $p$-amino benzoic acid (1), are used in the treatment of urinary track infections, eye infections and as a prophylaxis of rheumatic fever (2). Antibacterial sulfonamides act as competitive inhibitors of the enzyme dihydropteroate synthetase, DHPS, in bacteria. DHPS catalyses the conversion of PABA ( $p$-aminobenzoate) to dihydropteroate, a key step in folate synthesis, which is necessary for the cell to synthesize nucleic acids and thus exhibit a bacteriostatic effect (3).

Survey of the literature reveals various methods available for the determination of sulfonamide derivatives. The methods include the nitrite method (4), GC (5), HPLC (6, 7), HPTLC (8), electroanalytical methods (9-12), immune chemical assay $(13,14)$, spectrofluorimetry (15), differential scanning calorimetry (16), surface enhanced Raman spectrometry (17), spectrophotometry (18-22). Most spectrophotometric methods suffer from low sensitivity, high detection limits, tedious experimental conditions and complex procedures for the preparation of samples or standard solutions.

In the present study, we succeeded in developing a novel coupling agent for sensitive and selective spectrophotometric determination of the sulfonamide class of drugs

\footnotetext{
* Correspondence, e-mail: nagarajap58@yahoo.co.in
} 
P. Nagaraja et al:: A sensitive spectrophotometric method for the determination of sulfonamides in pharmaceutical preparations, Acta Pharm. 57 (2007) 333-342.

based on the coupling of their diazotized form with 8-hydroxyquinoline (8-HQ), which results in the formation of red coloured products in alkaline medium.

\section{EXPERIMENTAL}

\section{Apparatus}

A CHEMITO Model 2100 UV-VIS Spectrophotometer (Chemito Technologies Pvt Ltd., India) with 1-cm matched cells was used for all spectral and absorbance measurements.

\section{Reagents}

All the reagents and solvents were of analytical grade. The drugs selected for study were procured from Charak Pharma Pvt. Ltd. (India), and their structures are given in Table I: sulfacetamide (SFA, 99.0\%, Sigma Spain), sulfamethazine (SFMt, 99.0\%, Sigma China), sulfadiazine (SFD, 99.0\%, Sigma China) sulfaguanidine (SFG, 99.0\%, Sigma Switzerland), sulfamerazine (SFMr, 99.0\%, Sigma Belgium), sulfamethoxazole (SFMx, 99.0\%, Sigma Belgium).

Table I. Sulfonamide drugs studied

Sulfacetamide (SFA)


P. Nagaraja et al.: A sensitive spectrophotometric method for the determination of sulfonamides in pharmaceutical preparations, Acta Pharm. 57 (2007) 333-342.

Standard solution of sulfonamide $(1000 \mu \mathrm{g} \mathrm{mL}-1)$ was prepared by dissolving 100 mg each sulfonamide in $2.0 \mathrm{~mL}$ of sulfuric acid $\left(10 \mathrm{~mol} \mathrm{~L}^{-1}\right)$, then diluting with water to mark in a $100-\mathrm{mL}$ volumetric flask. A working standard solution of each sulfonamide containing $25 \mu \mathrm{g} \mathrm{mL}^{-1}$ was prepared by further dilution and was standardized by the British Pharmacopoeia method (4) and the reported method (21). An 8-HQ solution (0.5\%, $m / V)$, sodium nitrite $(1.0 \%, m / V)$ sulphamic acid $(2 \%, m / V)$, sodium hydroxide $(5 \mathrm{~mol}$ $\left.\mathrm{L}^{-1}\right)$ and sulphuric acid $(10 \mathrm{~mol} \mathrm{~L}-1)$ were prepared in water.

\section{General procedure}

Aliquots of standard sulfonamide solutions (SFMx, SFD, SFA, SFMt, SFMr and SFG) were transferred into $25-\mathrm{mL}$ calibrated flasks followed by $1.0 \mathrm{~mL}$ sulphuric acid to each. After cooling in an ice bath, $1.5 \mathrm{~mL}$ of sodium nitrite $(1.0 \% \mathrm{~m} / \mathrm{V})$ was added under swirling. The solutions were allowed to stand for $5 \mathrm{~min}$ and then $2.5 \mathrm{~mL}$ of sulphamic acid $(2.0 \%, \mathrm{~m} / \mathrm{V})$ was added, swirled and allowed to stand for $5 \mathrm{~min}$. Then $2.0 \mathrm{~mL}$ of $8-\mathrm{HQ}$ $(0.5 \%, \mathrm{~m} / \mathrm{V})$ was added, along with $2.0 \mathrm{~mL}$ of sodium hydroxide $\left(5 \mathrm{~mol} \mathrm{~L}^{-1}\right)$. The solution was made up to the mark with ethanol (95\%), mixed thoroughly and after 5 min the absorbance was measured at $500 \mathrm{~nm}$ against a reagent blank, and the calibration graph was constructed.

The limit of detection $(L O D)$ and quantification $(L O Q)$ were calculated according to the current ICH guidelines (23) as 3.3 and 10 standard deviation of the blank $(n=6)$ respectively, divided by the slope of the calculation curve.

The range of the error was calculated using the following mathematical relation (24):

$$
\frac{ \pm t S D}{\sqrt{n}}
$$

where $t=2.571$ (95\% confidence limit), $n=$ number of replicate determinations.

\section{Assay of commercial samples}

Tablets. - The following tablet formulations were purchased from local commercial sources and used for the analysis: Septran tablet (Burroughs Wellcome, India) each containing $400 \mathrm{mg}$ of SFMx, Sulphadiazine tablet (Rhone Poulenc, India) each containing $500 \mathrm{mg}$ of SFD.

Twenty tablets were powdered and mixed thoroughly. An amount equivalent to 50 mg sulfonamide was then dissolved in $20 \mathrm{~mL}$ of sulphuric acid $\left(1 \mathrm{~mol} \mathrm{~L}^{-1}\right)$ and filtered. The filtrate was made up to $100 \mathrm{~mL}$ and appropriate aliquots of the solution were treated as mentioned above in the general procedure.

Eye drops. - The following eye drop formulations were purchased from local sources and used for the analysis: Albucid (Nicholos-Pharmal India Ltd., India) containing 10 mg SFA mL ${ }^{-1}$, Locula (East India Ltd., India) containing $10 \mathrm{mg} \mathrm{SFA} \mathrm{mL}^{-1}$.

A volume of $5 \mathrm{~mL}$ of eye drops (equivalent to $50 \mathrm{mg}$ of SFA) was diluted with $2 \mathrm{~mL}$ of sulphuric acid $\left(10 \mathrm{~mol} \mathrm{~L}^{-1}\right)$ and made up to $100 \mathrm{~mL}$ with water. The general procedure was then followed. 
P. Nagaraja et al:: A sensitive spectrophotometric method for the determination of sulfonamides in pharmaceutical preparations, Acta Pharm. 57 (2007) 333-342.

\section{RESULTS AND DISCUSSION}

\section{Chemistry}

Sulfa drugs could be readily diazotized in acidic medium and the diazonium cation would then react with a molecule of 8 -HQ by electrophilic substitution at position- 4 of the coupling agent. The proposed method involves diazotization of sulfonamide derivatives followed by their coupling with 8-HQ to produce a red coloured azo product. Job's method of continuous variation for determining the composition of the product indicated that the reactants and reagents reacted in the 1:1 ratio. The proposed mechanism of reaction between 8-HQ and the sulfonamide drug is illustrated in Fig. 1. To ascertain the absorption maxima for sulfonamide derivatives, specified amounts of sulfonamide derivatives were taken and the coloured reaction products were developed as mentioned in the general procedure, and the absorption maxima were found to be $500 \mathrm{~nm}$. Fig. 2 shows the absorption spectrum of SFMx as the model compound. The resultant coloured product was found to be stable for about two days. The value of absorbance decreased above $30^{\circ} \mathrm{C}$. Hence, room temperature was preferred for the experiments. An attempt to increase the stability of the product beyond 48 hours failed.

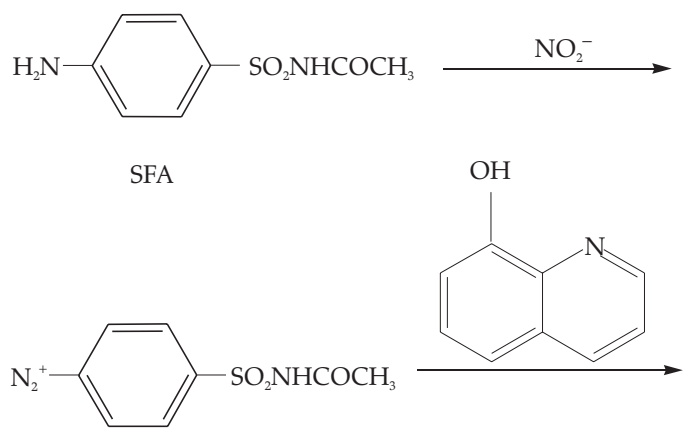

diazotized SFA

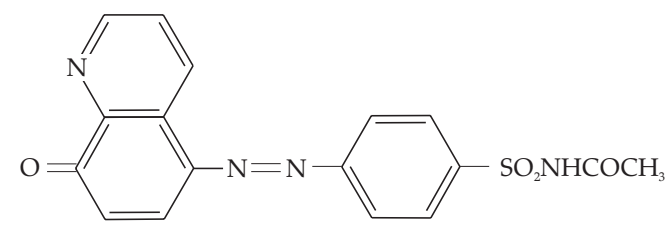

coupled product

Fig 1. Scheme of the proposed reaction mechanism. 
P. Nagaraja et al:: A sensitive spectrophotometric method for the determination of sulfonamides in pharmaceutical preparations, Acta Pharm. 57 (2007) 333-342.

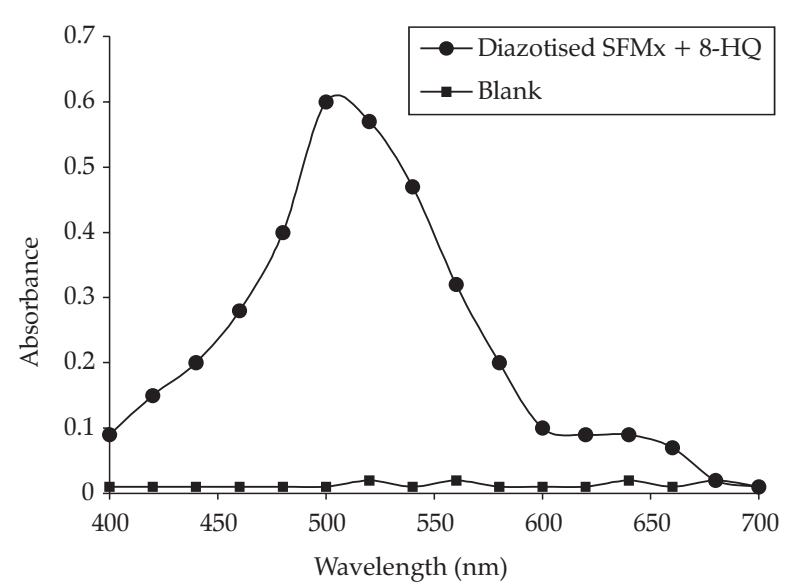

Fig. 2. Absorption spectrum of the reaction product of sulfamethoxazole (SFMx) with 8-HQ $\left(\lambda_{\max }=500 \mathrm{~nm}\right)$.

\section{Validation}

The intraday precision of the proposed method was examined by carrying out six replicate determinations of sulfonamides (within Beer's law range) by the proposed method. Table II summarizes the RSD values (0.1-0.5\%) and the range of error $(0.20-0.35$ at $95 \%$ confidence limit). The $L O D$ was found to be in the range of 0.03 to $0.05 \mu \mathrm{g} \mathrm{mL}^{-1}$ and $L O Q$ was in the range of 0.11 to $0.18 \mu \mathrm{g} \mathrm{mL}^{-1}$. The recovery ranged from $97.3 \pm 2.5 \%$ to $100.8 \pm 1.2 \%(n=6)$ (Table III).

The most promising feature of the proposed method is the freedom from interferences with the excipients commonly used in the pharmaceutical preparation of sulfonamide derivatives. Under optimum conditions, the effects of excipients and diluents such as talc, glucose, dextrose, lactose, etc., were investigated. An amount far in excess of that used in the pharmaceutical preparation was added in half the limit of Beer's law and no effect due to these excipients was found under the proposed experimental conditions. The recovery range was from $99.2 \pm 0.2 \%$ to $100.8 \pm 0.4 \%(n=6)$. The results are presented in Table IV.

\section{Application of the proposed method}

The applicability of the proposed method for the assay of different pharmaceutical formulations containing SFMx, SFD and SFA was examined for tablet and eye drops and the results were statistically compared with those obtained by the official method based on electrochemical titration (4) with $\mathrm{NaNO}_{2}$ and the reported spectrophotometric method (21) based on the reaction of drug with acetylacetone-formaldehyde reagent. The $t$-test and F-test were carried out, which showed that the proposed method and other established methods are of comparable accuracy and precision. The results are summarized in Table V. 
P. Nagaraja et al:: A sensitive spectrophotometric method for the determination of sulfonamides in pharmaceutical preparations, Acta Pharm. 57 (2007) 333-342.

Table II. Some analytical parametres for the spectrophotometric determination of sulfonamide derivatives

\begin{tabular}{lcccccc}
\hline Parameter & SFMx & SFD & SFA & SFMt & SFMr & SFG \\
\hline Colour & Red & Red & Red & Red & Red & Red \\
$\lambda_{\text {max }}(\mathrm{nm})$ & 500 & 500 & 500 & 500 & 500 & 500 \\
Stability $(\mathrm{h})$ & 48 & 48 & 42 & 48 & 46 & 48 \\
Beer's law range $\left(\mu \mathrm{g} \mathrm{mL}^{-1}\right)$ & $0.2-6.0$ & $0.1-5.0$ & $0.2-6.0$ & $0.3-7.0$ & $0.1-4.0$ & $0.19-6.0$ \\
Limit of detection $\left(\mu \mathrm{g} \mathrm{m}^{-1}\right)$ & 0.04 & 0.05 & 0.04 & 0.04 & 0.03 & 0.03 \\
Limit of quantitation $\left(\mu \mathrm{g} \mathrm{mL}^{-1}\right)$ & 0.15 & 0.16 & 0.15 & 0.18 & 0.12 & 0.11 \\
Molar absorptivity $\left(\mathrm{L} \mathrm{mol}^{-1} \mathrm{~cm}^{-1}\right)$ & $3.38 \times 10^{4}$ & $3.7 \times 10^{4}$ & $2.81 \times 10^{4}$ & $3.48 \times 10^{4}$ & $3.8 \times 10^{4}$ & $3.7 \times 10^{4}$ \\
\hline & Regression equation $(\mathrm{y})^{\mathrm{a}}$ & & & \\
\hline Slope (a) & 0.143 & 0.145 & 0.124 & 0.130 & 0.136 & 0.125 \\
Intercept (b) & 0.011 & 0.005 & 0.007 & 0.004 & 0.003 & 0.012 \\
Correlation coefficient $(R)$ & 0.9960 & 0.9984 & 0.9994 & 0.9980 & 0.9990 & 0.9992 \\
RSD $(\%)$ & 0.2 & 0.1 & 0.3 & 0.5 & 0.2 & 0.3 \\
Range of error & 0.3 & 0.2 & 0.4 & 0.3 & 0.2 & 0.3 \\
(95\% confidencee level) $(\%)$ & \multicolumn{7}{c}{0} & & & & \\
\hline
\end{tabular}

${ }^{\mathrm{a}} \mathrm{y}=\mathrm{a} \gamma+\mathrm{b}$ where $\gamma$ is the concentration in $\mu \mathrm{g} \mathrm{mL} \mathrm{L}^{-1}$.

Table III. Intraday accuracy and precision of the proposed method for SFMx

\begin{tabular}{|c|c|c|c|c|}
\hline \multirow{2}{*}{$\begin{array}{l}\text { Nominal concentration } \\
\quad \text { SFMx }\left(\mu \mathrm{g} \mathrm{mL} L^{-1}\right)\end{array}$} & \multicolumn{2}{|c|}{ SFMx found $(\%)^{a}$} & \multirow{2}{*}{$\begin{array}{l}\left(e_{\mathrm{r}}\right) \\
(\%)\end{array}$} & \multirow{2}{*}{$\begin{array}{c}\text { Paired } \\
t \text {-test }\end{array}$} \\
\hline & $\begin{array}{l}\text { Reported method } \\
(21)\end{array}$ & $\begin{array}{l}\text { Proposed } \\
\text { method }^{\mathrm{b}}\end{array}$ & & \\
\hline 1.0 & $99.7 \pm 1.8$ & $\begin{array}{c}97.3 \pm 2.5 \\
t=2.41 \\
F=1.93\end{array}$ & 2.4 & 2.005 \\
\hline 2.0 & $99.2 \pm 0.9$ & $\begin{array}{c}99.6 \pm 1.3 \\
t=0.75 \\
F=2.10\end{array}$ & 0.4 & \\
\hline 3.0 & $99.5 \pm 1.2$ & $\begin{array}{c}99.7 \pm 1.4 \\
t=0.35 \\
F=1.36\end{array}$ & 0.2 & \\
\hline 5.0 & $97.3 \pm 1.2$ & $\begin{array}{c}97.9 \pm 1.0 \\
t=1.70 \\
F=1.44\end{array}$ & 0.7 & \\
\hline 6.0 & $99.7 \pm 1.0$ & $\begin{array}{c}100.8 \pm 1.2 \\
t=2.12 \\
F=1.44\end{array}$ & 1.0 & \\
\hline
\end{tabular}

a Mean $\pm \mathrm{SD}, n=6$.

b Tabular $t$-value for d.f. 5 is 2.571; Tabular $F$-value for d.f. 5 is 5.05 . 
P. Nagaraja et al:: A sensitive spectrophotometric method for the determination of sulfonamides in pharmaceutical preparations, Acta Pharm. 57 (2007) 333-342.

Table IV. Interference studies of commonly used excipients

\begin{tabular}{|c|c|c|c|c|c|c|c|}
\hline \multirow{2}{*}{ Exicipient } & \multirow{2}{*}{$\begin{array}{c}\text { Conc. } \\
\left(\mathrm{mg} \mathrm{mL}^{-1}\right)\end{array}$} & \multicolumn{6}{|c|}{ Recovery $(\%)^{a, b}$} \\
\hline & & SFMx & SFD & SFA & SFMt & SFMr & SFG \\
\hline Gum acacia & 5.0 & $99.5 \pm 0.3$ & $99.2 \pm 0.3$ & $100.5 \pm 0.2$ & $99.2 \pm 0.3$ & $100.1 \pm 0.3$ & $99.2 \pm 0.3$ \\
\hline Talc & 5.0 & $100.1 \pm 0.3$ & $99.5 \pm 0.3$ & $99.2 \pm 0.4$ & $100.4 \pm 0.3$ & $100.1 \pm 0.3$ & $99.5 \pm 0.3$ \\
\hline Starch & 5.0 & $99.2 \pm 0.3$ & $99.2 \pm 0.3$ & $99.2 \pm 0.3$ & $99.4 \pm 0.2$ & $100.2 \pm 0.2$ & $99.6 \pm 0.3$ \\
\hline Dextrose & 3.5 & $99.2 \pm 0.3$ & $99.5 \pm 0.3$ & $99.6 \pm 0.3$ & $99.5 \pm 0.3$ & $99.6 \pm 0.3$ & $99.2 \pm 0.3$ \\
\hline Glucose & 3.0 & $99.6 \pm 0.3$ & $99.5 \pm 0.3$ & $99.7 \pm 0.2$ & $99.2 \pm 0.3$ & $99.6 \pm 0.3$ & $95.5 \pm 0.3$ \\
\hline Lactose & 4.0 & $100.2 \pm 0.3$ & $100.1 \pm 0.3$ & $100.2 \pm 0.2$ & $99.2 \pm 0.5$ & $100.7 \pm 0.3$ & $99.9 \pm 0.2$ \\
\hline $\begin{array}{l}\text { Carboxymethyl- } \\
\text { cellulose }\end{array}$ & 4.0 & $100.5 \pm 0.3$ & $99.2 \pm 0.2$ & $100.2 \pm 0.2$ & $100.8 \pm 0.4$ & $100.6 \pm 0.3$ & $99.8 \pm 0.4$ \\
\hline $\begin{array}{l}\text { Magnesium } \\
\text { stearate }\end{array}$ & 3.0 & $99.2 \pm 0.3$ & $99.2 \pm 0.3$ & $99.8 \pm 0.2$ & $99.7 \pm 0.3$ & $100.2 \pm 0.2$ & $99.9 \pm 0.2$ \\
\hline Sodium alginate & 4.0 & $99.3 \pm 0.6$ & $99.6 \pm 0.3$ & $99.8 \pm 0.3$ & $99.2 \pm 0.5$ & $99.9 \pm 0.2$ & $99.1 \pm 0.3$ \\
\hline Vitamin $\mathrm{B}_{6}$ & 3.8 & $100.3 \pm 0.3$ & $100.2 \pm 0.3$ & $100.6 \pm 0.3$ & $100.7 \pm 0.4$ & $100.3 \pm 0.3$ & $100.2 \pm 0.3$ \\
\hline
\end{tabular}

a Concentration of sulfonamide drug: $4 \mu \mathrm{g} \mathrm{mL} \mathrm{m}^{-1}$.

b Mean \pm SD, $n=6$.

The reported methods and the proposed method are compared in Table VI. For example, the proposed method is more simple and sensitive than the method including drug diazotization coupling with dopamine followed by complexation with molybdate ion reported earlier (28).

Table V. Determination of sulfonamide derivatives in pharmaceutical preparations

\begin{tabular}{|c|c|c|c|c|c|c|}
\hline \multirow[b]{2}{*}{ Sample } & \multirow{2}{*}{$\begin{array}{l}\text { Label } \\
\text { claim }\end{array}$} & \multicolumn{5}{|c|}{ Amount of drug found (in $\mathrm{mg})^{\mathrm{a}}$} \\
\hline & & $\begin{array}{l}\text { Proposed } \\
\text { method }\end{array}$ & $\begin{array}{c}\text { BP } \\
\text { method (4) }\end{array}$ & $\begin{array}{l}\text { Reported } \\
\text { method (21) }\end{array}$ & $t$-value & $F$-value \\
\hline $\begin{array}{l}\text { Septran } \\
(\mathrm{mg} \text { SFMx) }\end{array}$ & 400 & $398.00 \pm 0.70$ & $397.00 \pm 0.60$ & $397.00 \pm 0.80$ & 2.29 & 1.44 \\
\hline $\begin{array}{l}\text { Sulphadiazine } \\
(\mathrm{mg} \text { SFD) }\end{array}$ & 500 & $497.00 \pm 0.50$ & $496.00 \pm 0.60$ & $496.00 \pm 0.80$ & 2.29 & 1.44 \\
\hline $\begin{array}{l}\text { Albucid } \\
\left(\mathrm{mg} \mathrm{mL} \mathrm{mL}^{-1} \mathrm{SFA}\right)\end{array}$ & 10 & $9.90 \pm 0.30$ & $9.90 \pm 0.30$ & $9.75 \pm 0.30$ & 2.48 & 2.25 \\
\hline $\begin{array}{l}\text { Locula } \\
\left(\mathrm{mg} \mathrm{mL} \mathrm{L}^{-1} \mathrm{SFA}\right)\end{array}$ & 10 & $9.85 \pm 0.20$ & $9.80 \pm 0.30$ & $9.78 \pm 0.30$ & 2.50 & 1.96 \\
\hline
\end{tabular}

a Mean \pm SD, $n=6$.

Theoretical $t$-value $=2.776$; theoretical $F$-value $=6.39$. 
P. Nagaraja et al:: A sensitive spectrophotometric method for the determination of sulfonamides in pharmaceutical preparations, Acta Pharm. 57 (2007) 333-342.

Table VI. Comparison of reported spectrophotometric methods with the proposed method

\begin{tabular}{|c|c|c|c|c|c|c|}
\hline $\begin{array}{l}\text { Reagent(s) } \\
\text { used }\end{array}$ & $\begin{array}{l}\text { Sulfonamide } \\
\text { analyzed }\end{array}$ & $\begin{array}{l}\lambda_{\max } \\
(\mathrm{nm})\end{array}$ & $\begin{array}{c}\text { Beer's law } \\
\text { limits } \\
\left(\mu \mathrm{g} \mathrm{mL} \mathrm{mL}^{-1}\right)\end{array}$ & $\begin{array}{c}\text { Molar } \\
\text { absorptivity } \\
\left(\mathrm{L} \mathrm{mol} \mathrm{mom}^{-1} \mathrm{~cm}^{-1}\right.\end{array}$ & Reference & Remark \\
\hline p-Benzoquinone & $\begin{array}{c}\text { SFMx } \\
\text { and SFD }\end{array}$ & 500 & $10-50$ & & 25 & heating is needed \\
\hline o-Chloranil & SFA & 525 & $10-70$ & & 26 & \\
\hline $\begin{array}{l}\text { Phenol } \\
\text { and sodium } \\
\text { hypochlorite }\end{array}$ & SFG & 450 & $\begin{array}{l}\text { Not } \\
\text { reported }\end{array}$ & $1.65 \times 10^{4}$ & 27 & \\
\hline Dopamine & SFMx & 500 & $0.1-7.0$ & $2.67 \times 10^{4}$ & 28 & $\begin{array}{l}\text { diazotisation cou- } \\
\text { pling, product is } \\
\text { complexaton with } \\
\text { molybdate }\end{array}$ \\
\hline $\begin{array}{l}\text { 8-Hydroxy- } \\
\text { quinoline } \\
\text { (8-HQ) }\end{array}$ & SFMx & 500 & $0.2-6.0$ & $3.38 \times 10^{4}$ & $\begin{array}{l}\text { this } \\
\text { paper }\end{array}$ & $\begin{array}{l}\text { diazotization of } \\
\text { drug followed by } \\
\text { coupling with } 8-\mathrm{HQ}\end{array}$ \\
\hline
\end{tabular}

The proposed method was found to be simple, rapid, selective and more sensitive than most of the spectrophotometric methods available in literature. It does not involve heating, extraction and consumes less time. The products are stable for a sufficient interval of time making the method useful in practice.

\section{CONCLUSIONS}

The proposed method is simple, sensitive and free from drastic experimental conditions such as heating. It is also accurate and precise enough to be successfully adopted as an alternative to the existing spectrophotometric method and evaluation of drugs in pharmaceutical preparations to assure a high standard of quality control.

Acknowledgements. - One of the authors (Shailendra D. Naik) thanks the University of Mysore for the support to this research work.

\section{REFERENCES}

1. L. A. Mitscher, Antibiotics and Antimicrobial Agents, in Foye's Principles of Medicinal Chemistry (Eds. D. A. Williams and T. L. Lemke), $5^{\text {th }}$ ed., Lippincott Williams and Wilkins, Philadelphia 2002, pp. 819-862.

2. W. A. Petri, Jr., Antimicrobial Agents, in Goodman and Gilman's Pharmacological Basis of Therapeutics (Eds. J. G. Hardman and Lee E. Limbird), 10 ${ }^{\text {th }}$ Ed., McGraw Hill, New York 2001, pp. 11711188. 
P. Nagaraja et al:: A sensitive spectrophotometric method for the determination of sulfonamides in pharmaceutical preparations, Acta Pharm. 57 (2007) 333-342.

3. J. M. Beale, Jr., Anti Infective Agents, in Wilson and Gisvold's Text Book of Organic Medicinal and Pharmaceutical Chemistry (Eds. J. H. Block and J. M. Beale, Jr.), $11^{\text {th }}$ ed., Lippincott William and Wilkins, Philadelphia 2004, pp. 217-281.

4. British Pharmacopoeia, Vol II, Her Majesty's Stationery Office, London 2004, pp. 1858-1859.

5. B. Chivarino, M. A. Crestoni, A. Di-Marzio and S. Fornarini, Determination of sulfonamide antibiotics by gas chromatography coupled with atomic emission detection, J. Chromatogr. Biomed. Appl. 706 (1998) 269-277; DOI: 10.1016/S0378-4347(97)00568-9.

6. F. M. El Anwar, A. M. El Walily, M. H. Abdel Hay and M. El Swify, The analysis of a triple sulfonamide in pharmaceutical powder form by HPLC, Anal. Lett. 24 (1991) 767-779; DOI: 10.1080/ 00032719108052941.

7. G. K. Thomas, R. G. Millar and P. W. Antis, Stability of sulfonamide antibiotics in spiked pig liver tissue during frozen storage, JAOAC Int. 80 (1997) 988-995.

8. G. Knupp, H. Pollmann and D. Jonas, An improved HPTLC method for the rapid identification and quantification of sulfonamides, Chromatographia 22 (1986) 21-24; DOI: 10.1007/BF02257291.

9. C. L. Flurer, Analysis of antibiotics by capillary electrophoresis, Electrophoresis 18 (1997) 24272437; DOI: 10.1002/elps.1150181233.

10. F. Malecki and V. Starosak, Potentiometric determination of sulfonamides with a silver sulfide electrode, Anal. Chim. Acta 139 (1982) 353-357; DOI:10.1016/S0003-2670(01)94015-2.

11. M. T. Ackermans, J. L. Beckers, F. M. Everaerts, H. Hoogland and M. J. H. Tomassen, Determination of sulphonamides in pork meat extracts by capillary zone electrophoresis, J. Chromatogr. 596 (1992) 101-109; DOI: 10.1016/0021-9673(92)80209-D.

12. T. A. M. Msagati and J. C. Ngila, Voltammetric detection of sulfonamides at a poly(3-methylthiophene) electrode, Talanta 58 (2002) 605-610; DOI: 10.1016/S0039-9140(02)00327-2.

13. E. Martlbauer, E. Usleber, E. Schneider and R. Dietrich, Immunochemical detection of antibiotics and sulfonamides, Analyst 119 (1994) 2543-2548; DOI: 10.1039/AN9941902543.

14. S. W. Garden and P. Sporns, Development and evaluation of an enzyme immunoassay for sulfamerazine in milk, J. Agric. Food Chem. 42 (1994) 1379-1391; DOI: 10.1021/jf00042a026.

15. M. S. Pena, F. Salinas, M. C. Mahendero and J. J. Aaron, Spectrofluorimetric determination of sulphonamides in pharmaceutical compounds and foods, J. Pharm. Biomed. Anal. 10 (1992) 805808; DOI:10.1016/0731-7085(91)80084-M.

16. Y. M. Issa, A. L. El. Ansary and W. Selim, Enthalpimetric determination of sulfa drugs in pure form and pharmaceutical formulations, Anal. Lett. 31 (1998) 131-146; DOI: 10.1080/00032719808001838.

17. W. S. Sutherland, J. J. Laserna, M. J. Angebranndt and J. D. Winefordner, Surface-enhanced Raman analysis of sulfa drugs on colloidal silver dispersion, Anal. Chem. 62 (1990) 689-693; DOI: 10.1021/ac00206a008.

18. P. Nagaraja, K. R. Sunitha, R. A. Vasantha and H. S. Yathirajan, Iminodibenzyl as a novel coupling agent for the spectrophotometric determination of sulfonamide derivatives, Eur. J. Pharm. Biopharm. 53 (2002) 187-192; DOI:10.1016/S0939-6411(01)00235-1.

19. P. Nagaraja, H. S. Yathirajan, C. R. Raju, R. A. Vasantha, M. S. Hemantha Kumar and P. Nagendra, 3-Aminophenol as a novel coupling agent for the spectrophotometric determination of sulfonamide derivatives, Farmaco 58 (2003) 1295-1300; DOI: 10.1016/S0014-827X (03) 00093-4.

20. S. Raghuveer, I. R. K. Raju, D. K. Vastu and C. M. R. Shrivastava, Colorimetric determination of sulphamethoxazole in pharmaceutical preparations, Indian Drugs 30 (1993) 132-135.

21. A. S. Amin and M. M. Zarch, Acetylacetone-formaldehyde reagent for the spectrophotometric determination of some sulfa drugs in pure and dosage forms, Mikrochim. Acta. 124 (1996) 227233; DOI: $10.1007 / \mathrm{BF} 01242820$. 
P. Nagaraja et al: A sensitive spectrophotometric method for the determination of sulfonamides in pharmaceutical preparations, Acta Pharm. 57 (2007) 333-342.

22. S. S. Sabry, Enhanced spectrophotometry of sulfonamides with 2-acetylbutyrolactone derivatives, Anal. Lett. 39 (2006) 2591-2615; DOI: 10.1080/00032710600824748.

23. ICH Topic Q2(R1), Validation of Analytical Procedures: Text and Methodology (CPMP/ICH/281/95) acessed October 27, 2006.

24. R. A. Day, Jr. and A. L. Underwood, Errors and the Treatment of Analytical Data, in Quantitative Analysis, $6^{\text {th }}$ ed., Prentice-Hall of India, New Delhi 1999, pp. 7-42.

25. A. M. Mohamed, H. F. Askal and G. M. Saleh, Use of $p$-benzoquinone for the spectrophotometric determination of certain sulphonamides, J. Pharm. Biomed. Anal. 9 (1991) 531-538; DOI: 10.1016/ 0731-7085(91) 80174-8.

26. G. R. Rao, S. S. N. Murthy, P. J. Rao and I. R. K. Raju, Spectrophotometric determination of sulphacetamide sodium with o-chloranil in dosage form, Indian J. Pharm. Sci. 50 (1988) 138-140.

27. A. G. Fogg and N. M. Fayad, Spectrophotometric and differential pulse polarographic determination of sulphaguanidine by reaction with hypochlorite and phenol, Anal. Chim. Acta. 106 (1979) 365-367; DOI:10.1016/S0003-2670(01)85022-4.

28. P. Nagaraja, H. S. Yathirajan, K. R. Sunitha and R. A. Vasantha, A new sensitive and rapid spectrophotometric method for the determination of sulfa drugs, JAOAC Int. 85 (2002) 869-874.

$S A \check{Z} E T A K$

\section{Osjetljiva spektrofotometrijska metoda za određivanje sulfonamida u farmaceutskim pripravcima}

PADMARAJAIAH NAGARAJA, SHAILENDRA D. NAIK, ASHWINEE KUMAR SHRESTHA i ANANTHARAMAN SHIVAKUMAR

U radu je opisana nova, jednostavna i osjetljiva spektrofotometrijska metoda za određivanje sulfonamida. Metoda se temelji na prevođenju sulfacetamida, sulfadiazina, sulfagvanidina, sulfamerazina, sulfometazina i sulfametoksazola u diazoderivate koji kondenzacijom s 8-hidroksikinolinom $u$ alkalnom mediju daju crveno obojene produkte $s$ maksimumom apsorpcije pri $500 \mathrm{~nm}$. Beerov zakon vrijedi u koncentracijskom rasponu $0,1-7,0 \mu \mathrm{g} \mathrm{mL}-1$. Granice kvantifikacije i granice detekcije su $0,11-0,18$, odnosno $0,03-0,5$ $\mu \mathrm{g} \mathrm{mL} \mathrm{m}^{-1}$. Za predloženu metodu procijenjena je intermedijarska preciznost (RSD 0,1-0,5\%) i točnost (analitički povrat 97,3-100,8). Uobičanjene pomoćne tvari u tabletama ne interferiraju tijekom određivanja. Metoda je uspješno primijenjena za analizu sulfonamida u farmaceutskim pripravcima.

Ključne riječi: sulfonamidi, diazotacija, 8-hidroksikinolin, spektrofotometrija, farmaceutski pripravak

Department of Studies in Chemistry, University of Mysore, Manasagangothri, Mysore-570006, India

Charak Pharma Pvt. Ltd., Silvassa, U. T. of Dadra Nagar Haveli, Silvassa-396230, India 